\title{
CHILDREN AND ARSON
}

America's Middle Class

Nightmare 


\section{CHILDREN AND ARSON America's Middle Class Nightmare}

Wayne S. Wooden and Martha Lou Berkey 


\section{Library of Congress Cataloging in Publication Data}

Wooden, Wayne S.

Children and arson.

Bibliography: $p$.

Includes index.

1. Arson-United States-Psychological aspects-Case studies. 2. Juvenile delinquents-United States-Attitudes-Case studies. 3. Adolescent psychology-United States-Case studies. 4. Criminal psychology-Case studies. I. Berkey, Martha Lou. II. Title.

(C) 1984 Wayne S. Wooden and Martha Lou Berkey

Softcover reprint of the hardcover 1st edition 1984

Plenum Press is a Division of

Plenum Publishing Corporation

233 Spring Street, New York, N.Y. 10013

All rights reserved

No part of this book may be reproduced, stored in a retrieval system, or transmitted in any form or by any means, electronic, mechanical, photocopying, microfilming, recording, or otherwise, without written permission from the Publisher 
I hear the alarm at dead of night,

I hear the bells-shouts!

I pass the crowd-I run!

The sight of flames maddens me with pleasure.

Walt Whitman, Poems of Joy, 1860 


\section{ACKNOWLEDGMENTS}

The authors would like to take this opportunity to thank the many individuals who contributed to this book.

A special appreciation goes to Paul Boccumini, Director of Clinical Services for the San Bernardino County Probation Department, and the Probation Department's staff, including Barbara Ward-lawe and Stan Brown. We wish to thank Keith Griffiths, Norman Skonovd, Roy Lewis, Carl Jesness, and James Turner of the research division of the California Youth Authority. Joseph D. Piscioneri was also most helpful in this project. A particular thanks to Kevin Bolinger for his assistance with the statistical analysis of the study. We are equally indebted to Peter M. Nardi and Gary A. Cretser for their editorial comments on earlier drafts of the manuscript.

Others we wish to acknowledge include Kenneth $\mathrm{R}$. Fineman, John Barracato, Dewey Willis, Charlotte Rhea, Saul Niedorf, Dudley Sams, Tom Hopkinson, L. H. Jacobson, Doug McClure, Cal Terhune, Susan Wolfe, John C. Lee, and Jan Gratton.

We also appreciate the special consideration given to us by the School of Arts and the Department of Behavioral Sciences of California State Polytechnic University, Pomona, in providing us with release time and supplies to complete the project.

Finally, we wish to express our deep appreciation to Linda Greenspan Regan, our editor at Plenum. She has offered invaluable help in putting this volume together. 
We would also like to acknowledge our production editor, James Knierim, for his work in the production stages of this book.

On a sad note, Martha Lou Berkey succumbed to cancer during the completion of this project. She leaves behind a husband and two daughters. Her special warmth and understanding will be missed. This book stands in her memory as she cared about and helped these young firesetters.

WAYNE S. WOODEN 


\section{CONTENTS}

Chapter 1: Introduction to the Problem 1

Chapter 2: The Burning of America 7

Chapter 3: Behavioral Characteristics of Firesetters 21

Chapter 4: "Playing-with-Matches" Firesetters

Chapter 5: "Crying-for-Help" Firesetters 51

Chapter 6: "Delinquent" Firesetters 63

Chapter 7: "Severely Disturbed" Firesetters 83

Chapter 8: Sexual Concerns and Arson 93

Chapter 9: Juvenile Arsonists in Prison 113

Chapter 10: From Firebugs to Fire Fighters? 135

Chapter 11: To Catch an Arsonist 165

Chapter 12: Treatment of the Offender 179

Chapter 13: Strategies for the Future 197

Notes 207

Appendix A: Questionnaires 215

Appendix B: Methodology and Tables 235

Appendix C: "Learn Not to Burn" Knowledge Test 253

Index 259 